\title{
New Enzyme Reactor with Forced Flow of the Substrate through an Enzyme Immobilized Ceramic Membrane
}

\author{
Mitsutoshi Nakajima, Atsuo Watanabe, Hiroshi Nabetani, \\ Hiroyuki HorIKITA* and Shin-ichi NAKAO** \\ National Food Research Institute, Ministry of Agriculture, Forestry and Fisheries, \\ Tsukuba, Ibaraki 305, Japan \\ * NGK Insulators Ltd., Sudacho, Nagoya 475, Japan \\ ** Department of Chemical Engineering, Faculty of Engineering, \\ University of Tokyo, Hongo, Tokyo 113, Japan
}

Received August 10, 1987

\begin{abstract}
A new enzyme reactor system for low-moleçular-weight substrates, utilizing forced flow through an enzyme-immobilized membrane, was developed. Invertase was physically immobilized within a porous ceramic membrane by filtering an enzyme solution, and a sucrose solution was forced through the membrane by pressure, using a crossflow filtration method. The reaction rate of the forced-flow system was more than 10 times greater than that observed in a diffusion-controlled system. The reaction rate in both systems was mathematically modeled, and the simulated results were in good agreement with the experimental results. The reaction rate in the forced-flow system was easily controlled by pressure, and its productivity was greater than those reported in other reactor systems.
\end{abstract}

In the past two decades, much research has been conducted into immobilized enzyme and microbial cell technology, and several successful industrial applications have been developed; e.g., the production of high-fructosecontent syrup by immobilized glucose isomerase, the production of L-amino acid by immobilized amino-acylase, and continuous ethanol fermentation using immobilized yeast cells."

Research into membrane technology has also resulted in many industrial applications. In particular, the techniques of reverse osmosis and ultrafiltration have found wide-spread use. ${ }^{2)}$ Inorganic membranes, which have high durability against heat and chemical agents, can be advantageously combined with enzyme reactions in a membrane bioreactor (MBR), the enzyme usually being trapped on one side of the membrane. A substrate is supplied and a product permeates through the membrane, the enzyme being retained for further reactions. Such reactors can be operated continuously with high productivity. ${ }^{3 \sim 5)}$ An MBR can be classified into several types according to its configuration, the advantages of each type for enzyme reactions having been summarized. ${ }^{3,6)}$

One type of MBR is a continuous, stirred tank reactor with an ultrafiltration membrane (CSTR/UF), which can be used for the hydrolysis of high-molecular-weight substrates such as proteins ${ }^{7,8)}$ and cellulose, ${ }^{9 \sim 11}$ and for the solubilization of fish protein by trypsin. ${ }^{21}$

Another type of MBR is a hollow-fiber reactor, which is used mainly for lowmolecular-weight substrates. Generally, enzymes are retained on the shell side, and substrates flowing through the lumen/tube side diffuse to the shell side and react with the enzyme. The products diffuse back to the lumen/tube side. Hydrolysis of raffinose ${ }^{13)}$ and maltose ${ }^{14)}$ and the hydrolysis of lactose in untreated whey or skim milk by $\beta$-galactosidase have been reported in laboratory and pilot-plant studies. ${ }^{15)}$ 
For a practical evaluation of MBRs, the value of productivity per reactor volume or productivity per unit of enzyme is important. Hollow-fiber reactors have the disadvantage of limited diffusion, that is, the productivity is limited by the diffusivities of substrates and products. ${ }^{6)}$ In one case involving the hydrolysis of sucrose using a CSTR/UF system, the productivity was low because the substrate permeated through the membrane. ${ }^{16)}$

The basis of this study is that the hydrolysis of low-molecular-weight substrates could be more effective if pressure was used to force the flow of substrates through an ultrafiltration membrane in which an enzyme was immobilized. The driving force.for controlling the rate of reaction would be pressure, rather than diffusion. For practical purposes, a cross-flow filtration process could be more suitable than a dead-end filtration process. In reacent research on the hydrolysis of lactose in whole whey, such a forced-flow system has been applied using a commercially available PVC-silica microfiltration membrane. ${ }^{17)}$ High conversion was reported with a short residence time of 1.5 min. A prototype of the forced-flow system with a polymer membrane has been also commercialized, ${ }^{18)}$ and has been applied to the hydrolysis of starch by glucoamylase. ${ }^{19)}$

The purpose of this study was to investigate a new type of MBR system with forced substrate flow for the hydrolysis of low-molecular- weight substrates, using an enzyme physically immobilized onto and within a ceramic membrane.

In conventional column-immobilized systems, internal diffusion of the substrates and products may limit the reaction rates. ${ }^{1)}$ To determine the effect of internal diffusion, the same enzyme-immobilized ceramic membrane was used in both the forced-flow and diffusioncontrolled systems. Theoretical modeling of and experiments with both the forced-flow and diffusion-controlled systems for sucrose inversion by invertase were carried out.

\section{THEORETICAL MODELING}

One mole of sucrose is converted stoichiometrically into one mole of glucose and fructose. The forced-flow system is shown schematically in Figs. 1a and b. A substrate solution flows from the outer wall to the inner wall through a porous cylindrical membrane by a pressure difference, and reacts within the porous membrane where the enzyme is immobilized. From an analysis of a plug flow model with back diffusion and reaction, the following equations were obrained, assuming the same bulk diffusion coefficients for sucrose, glucose and fructose in solution. Although a substrate inhibition model for sucrose inversion has been reported, ${ }^{20,21)}$ the reaction rate can be approximated by the simple Michaelis-

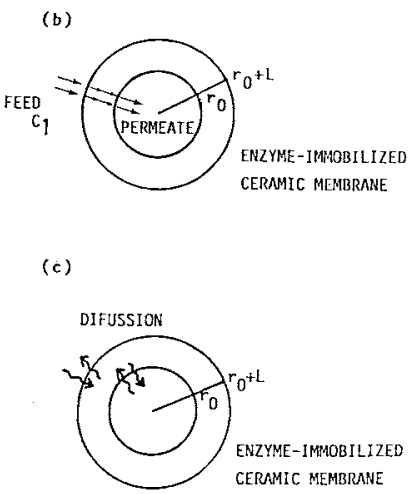

FIG. 1. Schematic Descriptions of the Forced-flow and Diffusion-controlled Systems.

(a), illustration of the forced-flow system; (b), scheme for the forced-flow system; (c), scheme for the diffusioncontrolled system. 
Menten formula, in which the sucrose concentration is the low range of $26 \sim 260$ $\mathrm{mol} \cdot \mathrm{m}^{-3}$.

$$
\begin{aligned}
& D\left[(1 / r)(\mathrm{d} C / \mathrm{d} r)+\mathrm{d}^{2} C / \mathrm{d} r^{2}\right]+u(\mathrm{~d} C / \mathrm{d} r) \\
& \quad-V_{\mathrm{m}} C /\left(C+K_{\mathrm{m}}\right)=0 \\
& C+G=C_{1} \\
& u=u_{1}\left(r_{0}+L\right) / r
\end{aligned}
$$

B.C. $\mathrm{d} C / \mathrm{d} r=0$ at $r=r_{0}$,

$$
C=C_{1} \quad \text { at } \quad r=r_{0}+L
$$

where $C$ is the sucrose concentration of the solution in a porous membrane $\left(\mathrm{mol} \cdot \mathrm{m}^{-3}\right), C_{1}$ the sucrose concentration in the feed solution $\left(\mathrm{mol} \cdot \mathrm{m}^{-3}\right), G$ the glucose concentration (mol . $\mathrm{m}^{-3}$ ), $D$ the bulk diffusion coefficient in liquid $\left(\mathrm{m}^{2} \cdot \mathrm{sec}^{-1}\right), u$ the linear permeation velocity of the solution in a porous membrane from the feed to permeate side $\left(\mathrm{m} \cdot \mathrm{sec}^{-1}\right), u_{1}$ the linear permeation velocity at the outer wall of the membrane $\left(\mathrm{m} \cdot \mathrm{sec}^{-1}\right), r_{0}$ the inner radius of the membrane (m), $L$ the thickness of the ceramic membrane $(\mathrm{m}), r$ the radial coordinate $(\mathrm{m}), V_{\mathrm{m}}$ the maximum reaction rate in liquid within the membrane $\left(\mathrm{mol} \cdot \mathrm{m}^{-3} \cdot \mathrm{sec}^{-1}\right), K_{\mathrm{m}}$ the MichaelisMenten constant (which was assumed to be $9 \mathrm{~mol} \cdot \mathrm{m}^{-322)}$ ). If we assume that the enzyme is immobilized homogeneously, $V_{\mathrm{m}}$ in Eq. (1) may become constant.

These equations can be expressed in nondimensional form.

$$
\begin{aligned}
& -\alpha\left(\mathrm{d}^{2} \theta / \mathrm{d} \xi^{2}\right)-\beta_{\mathrm{u}}(\xi)(\mathrm{d} \theta / \mathrm{d} \xi)+\theta /(\theta+\gamma)=0 \\
& \theta+\tau=1
\end{aligned}
$$

B.C. $\mathrm{d} \theta / \mathrm{d} \xi=0$ at $\xi=0$,

$$
\theta=1 \quad \text { at } \quad \xi=1
$$

where

$$
\begin{gathered}
\theta=C / C_{1}, \quad \tau=G / C_{1}, \quad \xi=\left(r-r_{0}\right) / L, \\
\alpha=C_{1} D /\left(V_{\mathrm{m}} L^{2}\right) \\
\beta_{\mathrm{u}}(\xi)=\frac{C_{1} u_{1}\left(1+r_{0} / L+D /\left(u_{1} L\right)\right)}{V_{\mathrm{m}} L\left(\xi+r_{0} / L\right)}, \quad \gamma=K_{\mathrm{m}} / C_{1}
\end{gathered}
$$

The sucrose flux due to convective flow can be determined from the permeation velocity, sucrose concentration of the feed, and the porosity. The glucose flux due to convective flow can be determined from the permeation velocity, glucose concentration of the permeate, and the porosity. These fluxes can be expressied as:

$U_{\mathrm{s}}$ (sucrose flux due to convective flow)

$$
=\varepsilon C_{1} u_{1}
$$

$U_{\mathrm{g}}$ (glucose flux due to convective flow)

$$
=\varepsilon C_{1} u_{1} \tau \quad \text { at } \quad \xi=0
$$

where $\varepsilon$ is the porosity. It can be noted that $U_{\mathrm{s}}$, which is supplied from the outer wall into the membrane due to convective flow, is the same as $U_{\mathrm{g}}$ plus the flux of unchanged sucrose due to convective flow at the inner wall.

Even in the case of a forced-flow system, some of the glucose produced diffuses back into the feed solution. The glucose flux due to diffusion in a forced-flow system can be expressed as:

$N_{\mathrm{g}}$ (glucose flux due to diffusion)

$$
=\varepsilon C_{1} D(\mathrm{~d} \tau / \mathrm{d} \xi) \quad \text { at } \quad \xi=1
$$

From mass balance, $N_{\mathrm{g}}$ is the same as the sucrose flux due to diffusion at the outer wall.

Consider a diffusion-controlled system, that is, a reaction system with an immobilized enzyme membrane in a stirred vessel as shown in Fig. 1c. The substrate diffuses from the outer and inner walls into a porous membrane, a reaction occurs and products diffuse back into the surrounding liquid. This system can be modeled as follows:

$$
D\left((1 / r)(\mathrm{d} C / \mathrm{d} r)+\mathrm{d}^{2} C / \mathrm{d} r^{2}\right)-V_{\mathrm{m}} C /\left(C+K_{\mathrm{m}}\right)=0
$$

$C+G=C_{1}$

$$
\begin{aligned}
\text { B.C. } \quad C=C_{1} \quad \text { at } \quad r=r_{0}, \\
C=C_{1} \quad \text { at } \quad r=r_{0}+L
\end{aligned}
$$

where the notation is the same as that shown below Eq. (4). These equations can also be expressed in non-dimensional form. 
$-\alpha\left(\mathrm{d}^{2} \theta / \mathrm{d} \xi^{2}\right)-\beta_{\mathrm{d}}(\mathrm{d} \theta / \mathrm{d} \xi)+\theta /(\theta+\gamma)=0$.

$\theta+\tau=1$

B.C. $\theta=1$ at $\xi=0$,

$$
\theta=1 \quad \text { at } \xi=1
$$

where $\beta_{\mathrm{d}}=C_{1} D /\left(V_{\mathrm{m}} L^{2}\left(\xi+r_{0} / L\right)\right)$

The glucose flux due to diffusion in a diffusion-controlled system can be expressed as follows, on the basis of the surface area of the outer wall of a membrane.

$$
\begin{array}{ll}
N_{\mathrm{g} 0}=\varepsilon C_{1} D(\mathrm{~d} \tau / \mathrm{d} \xi) & \text { at } \quad \xi=0 \\
+\varepsilon C_{1} D\left(r_{0} /\left(r_{0}+L\right)\right)(\mathrm{d} \tau / \mathrm{d} \xi) & \text { at } \quad \xi=1
\end{array}
$$

Equations (5), (6), (15) and (16) can be solved numerically by the successive overrelaxation (SOR) method $^{23)}$ using a microcomputer, and $U_{\mathrm{s}}, U_{\mathrm{g}}, N_{\mathrm{g}}$ and $N_{\mathrm{g} 0}$ can be calculated from Eqs. (9), (10), (11) and (19).

\section{MATERIALS AND METHODS}

Immobilization of the enzyme. The experimental apparatus used is schematically shown in Fig. 2. An alumina ceramic membrane of $5 \mathrm{~mm}$ outer diameter, $50 \mathrm{~cm}$ length and $1.8 \mathrm{~mm}$ thickness was used as the support for enzyme immobilization, this membrane being asymmetric. The average pore size of the outer skin layer was $50 \mathrm{~nm}$, and that of the inner support layer was about $1 \mu \mathrm{m}$. The average porosity was 0.4 . The ceramic membrane was inserted into a cylindrical stainless steel pressure vessel of $6 \mathrm{~mm}$ inner diameter, and sealed with two O-rings. The effective membrane area of the module was $78 \mathrm{~cm}^{2}$, and the temperature of the feed solution was controlled to within $\pm 1.5^{\circ} \mathrm{C}$.

Invertase (Candida utilis, mean M.W. 30000 , pI 3.8 , optimum $\mathrm{pH} 4.5$ ), manufactured by Wako Chem. Co. (Japan), was used. An enzyme solution of pH 3.8 (adjusted using an acetate buffer) was circulated along the outer skin layer at a pressure of $1.0 \mathrm{MPa}$ and flow rate of $1000 \mathrm{~cm}^{3}$. $\min ^{-1}$. All the permeate was returned to the feed tank during circulation. After a defined period, circulation was stopped, and the enzyme solution on the retentate side of the module and in the membrane was removed by crossflow filtration of pure water at a pressure of $0.2 \mathrm{MPa}$. The enzyme-immobilized ceramic membrane so obtained was stored in pure water. Two immobilization conditions were employed, the first with an enzyme concentration of the circulated solution of $275 \mathrm{~g} \cdot \mathrm{m}^{-3}$ and an immobilization time of $2 \mathrm{hr}$ at $30^{\circ} \mathrm{C}$, and the second with an enzyme

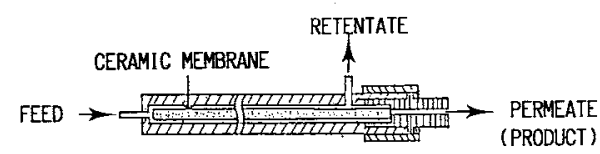

PRESSURE VESSEL

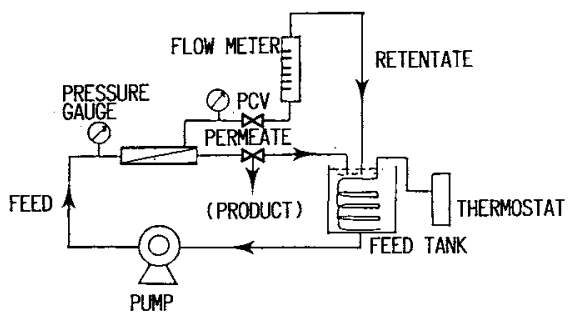

FIG. 2. Schematic Diagram of the Experimental Apparatus and Details of the Ceramic Membrane Module Used in the Foreed-fiow System.

concentration of $20 \mathrm{~g} \cdot \mathrm{m}^{-3}$ and immobilization time of $20 \mathrm{hr}$ at $15^{\circ} \mathrm{C}$.

Enzyme reaction in the forced-flow system. Using enzyme-immobilized membranes, sucrose solutions were fed using crossflow filtration at pressures of $0.08 \sim 1.0$ $\mathrm{MPa}$, flow rates of $1000 \sim 2400 \mathrm{~cm}^{3} \cdot \mathrm{min}^{-1}$ (mean axial velocities of $1.9 \sim 4.6 \mathrm{~m} \cdot \mathrm{sec}^{-1}$ ), and a temperature of $30^{\circ} \mathrm{C}$. Sucrose concentrations were 26 and $260 \mathrm{~mol} \cdot \mathrm{m}^{-3}$. The $\mathrm{pH}$ value of the feed solution was controlled at 4.5 using an acetate buffer. The concentrations of sucrose, glucose and fructose were measured by HPLC with a finely packed SIL-NH $\mathrm{N}_{2}$ column (Nihon Bunko Co.).

Enzyme reaction in the diffusion-controlled system. The enzyme-immobilized ceramic membrane made by the first method was cut into $3 \sim 5 \mathrm{~cm}$ pieces, which were then placed in a stirred vessel. The sucrose concentration was $26 \mathrm{~mol} \cdot \mathrm{m}^{-3}$, and the $\mathrm{pH}$ value of the solution was adjusted to 4.5 using an acetate buffer. The changes of glucose, fructose and sucrose concentrations with time were determined by HPLC.

\section{RESULTS AND DISCUSSION}

\section{Immobilization of the enzyme}

The changes of permeate flux through the ceramic membrane during enzyme immobilization using both immobilization conditions are shown in Fig. 3. The permeate flux decreased with time, $30 \sim 40 \%$ of enzyme in terms of protein concentration being rejected during immobilization. From these results, the enzyme entered the membrane, and a certain amount of the enzyme was adsorbed or plugged within the membrane. 

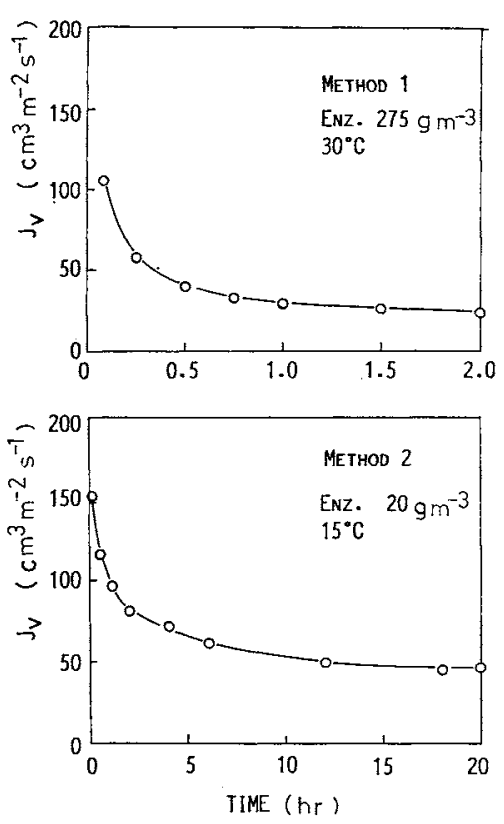

Fig. 3. Permeate Flux Decline with Time during the Process of Immobilization of an Enzyme within a Ceramic Membrane.

\section{Enzyme reaction}

The permeate flux and substrate conversion using an enzyme-immobilized ceramic membrane produced by the first method are shown in Fig. 4, the permeate flux being almost proportional to the applied pressure. Little effect of flow rate on the permeate flux was observed in the range of $1000 \sim 2400 \mathrm{~cm}^{3}$. $\min ^{-1}$. When the permeate flux was low and sucrose concentration was $26 \mathrm{~mol} \cdot \mathrm{m}^{-3}$, the conversion was almost $100 \%$. However, when the sucrose concentration was $260 \mathrm{~mol} \cdot \mathrm{m}^{-3}$, the conversion was rather low. The relationships between the sucrose flux due to convective flow $\left(U_{\mathrm{s}}\right)$ and the glucose flux due to convective flow $\left(U_{\mathrm{g}}\right)$ using membranes produced by both immobilization methods are shown in Fig. 5. $U_{\mathrm{s}}$ indicates the amount of sucrose input accompanied by permeate flow, while $U_{\mathrm{g}}$ indicates the amount of glucose output accompanied by permeate flow. The conversions obtained were almost $100 \%$ with low sucrose flux. When the sucrose flux increased, the conversion decreased, and the reaction rate due to convective flow reached a plateau value.
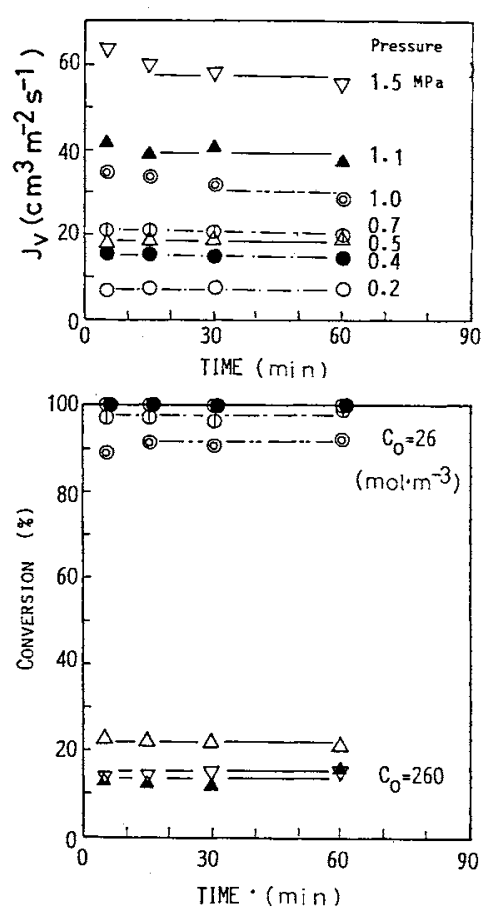

FIG. 4. Permeate Flux and Substrate Conversion with an Enzyme-immobilized Membrane Prepared by the First Method.

Such values were different between the membranes prepared by each immobilization method, possibly because of the different amounts of enzyme immobilized.

In the diffusion-controlled system, using the enzyme-immobilized membrane made by the first method, the concentration of glucose increased almost linearly with time. The reaction rate obtained per unit of surface area of the outer and inner walls of the membrane was $0.064 \mathrm{mmol} \cdot \mathrm{m}^{-2} \cdot \mathrm{sec}^{-1}$. The reaction rate on the basis of the outer wall area $\left(N_{\mathrm{go}}\right.$ in Eq. (19)) was calculated to be $0.083 \mathrm{mmol} \cdot \mathrm{m}^{-2} \cdot \mathrm{sec}^{-1}$. This rate was much lower than that with the forced-flow system, which is indicated on the $y$-ordinate in Fig. 6. The effectiveness factor of the enzyme in the forced-flow system was found to be much higher than that in the diffusion-controlled system. In Fig. 6, the glucose flux due to diffusion as a function of the maximum reaction rate is depicted. If we use the molecular diffusion coefficient of sucrose $\left(4 \times 10^{-10} \mathrm{~m}^{2} \cdot \mathrm{sec}^{-124)}\right)$ as $D$, the value of the 


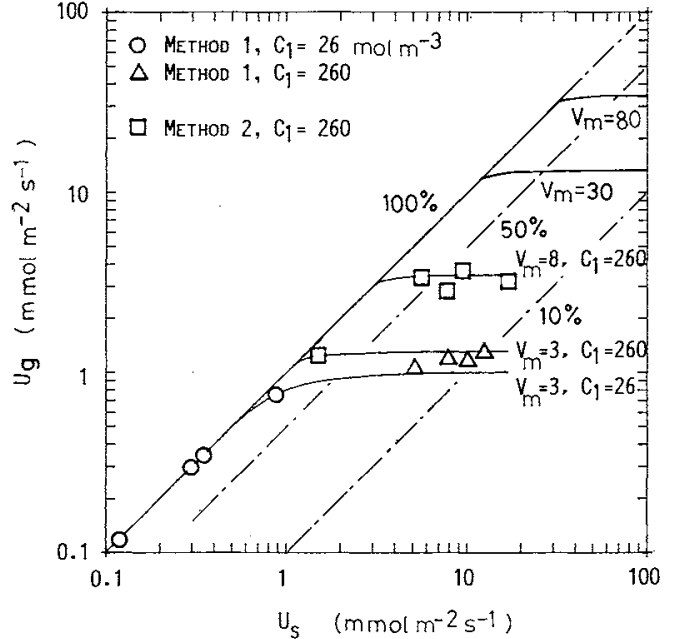

FIG. 5. Comparison between Glucose Flux due to Convective Flow $\left(U_{\mathrm{s}}\right)$ and Sucrose Flux due to Convective Flow $\left(U_{\mathrm{s}}\right)$ in the Forced-flow System.

Symbols of circles, triangles and squares are experimental values under $C_{1}$ of 26 and $260 \mathrm{~mol} \cdot \mathrm{m}^{-3}$ with the membrane by the first immobilization method, and under $C_{1}$ of $260 \mathrm{~mol} \cdot \mathrm{m}^{-3}$ with the membrane by the second immobilization method, respectively. The lower three solid lines are simulated under $V_{\mathrm{m}}$ of $3 \mathrm{~mol} \cdot \mathrm{m}^{-3} \cdot \mathrm{sec}^{-1}$ and $C_{1}$ of 26 and $260 \mathrm{~mol} \cdot \mathrm{m}^{-3} \cdot \mathrm{sec}^{-1}$, and under $V_{\mathrm{m}}$ of $8 \mathrm{~mol} \cdot \mathrm{m}^{-3} \cdot \mathrm{sec}^{-1}$ and $C_{1}$ of $260 \mathrm{~mol} \cdot \mathrm{m}^{-3} \cdot \mathrm{sec}^{-1}$, respectively. The upper two solid lines are simulated under $C_{1}$ of $260 \mathrm{~mol} \cdot \mathrm{m}^{-3} \cdot \mathrm{sec}^{-1}$, and $V_{\mathrm{m}}$ of 30 and $80 \mathrm{~mol} \cdot \mathrm{m}^{-3} \cdot \mathrm{sec}^{-1}$, respectively. The three broken lines show conversions of $100 \%, 50 \%$ and $10 \%$.

maximum reaction rate with the first immobilization method was estimated to be about $3 \mathrm{~mol}$. $\mathrm{m}^{-3} \cdot \mathrm{sec}^{-1}$. This value was used for simulating the forced-flow system using a membrane made by the first immobilization method.

The simulated results for the forced-flow system are shown in Fig. 5. In the case of the first immobilization method, these coincided fairly well with the experimental results. The value of the maximum reaction rate with the membrane made by the second immobilization method was not determined. Assuming that the maximum reaction rate was equal to $8 \mathrm{~mol}$. $\mathrm{m}^{-3} \cdot \mathrm{sec}^{-1}$, the experimental values were well simulated.

For the foregoing analysis, we assumed a one-dimensional model for the radial direction. The recirculation flow-rate of substrate solution through the membrane module was

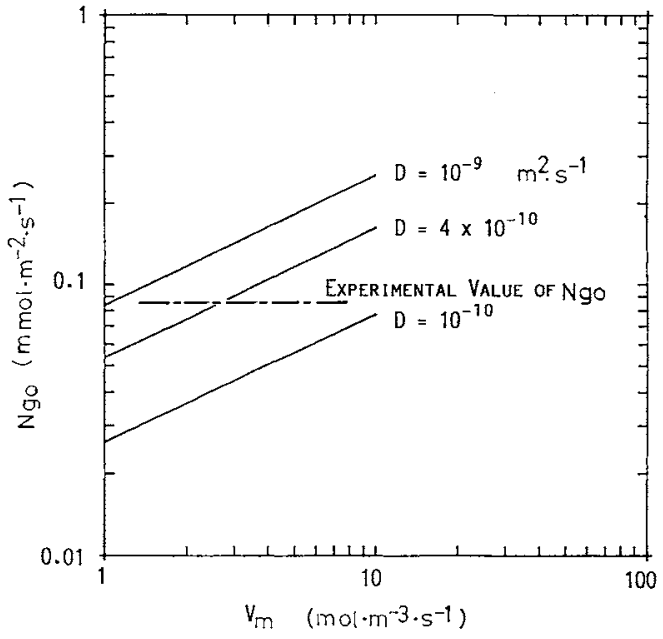

Fig. 6. Glucose Flux due to Diffusion $\left(N_{\mathrm{g} 0}\right)$ as a Function of the Maximum Reaction Rate $\left(V_{\mathrm{m}}\right)$ in the Diffusion-controlled System.

The chain line shows the experimental glucose flux due to diffusion under a substrate concentration of $26 \mathrm{~mol} \cdot \mathrm{m}^{-3}$, using cut pieces of the membrane produced by the first immobilization method. Solid lines are simulated values under three different bulk diffusion coefficients $(D)$.

$1000 \sim 2400 \mathrm{~cm}^{3} \cdot \mathrm{min}^{-1}$, whereas the maximum permeate flow-rate was $28 \mathrm{~cm}^{3} \cdot \mathrm{min}^{-1}$. The recirculation flow-rate was therefore much higher than permeate flow-rate, and any variation of the substrate solution along the axis may be considered negligible.

A computer simulation of the glucose flux due to diffusion in the forced-flow system was conducted using Eq. (11). The glucose flux to the retentate due to diffusion, which was thought to be the same as the sucrose flux from the retentate to membrane due to diffusion, was simulated in the range $0.001 \sim 0.1 \mathrm{mmol}$. $\mathrm{m}^{-2} \cdot \mathrm{sec}^{-1}$. In the range of high glucose flux due to convective flow, the glucose flux due to diffusion was estimated to be $2 \sim 3$ orders lower than that due to convective flow. The effect of back diffusion in the forced-flow system was therefore considered negligible. It was found that the amount of sucrose supplied into membrane was almost equal to the sucrose flux due to convective flow, and the amount of glucose produced in membrane was almost equal to the glucose flux due to con- 
vective flow.

As can be seen in Fig. 5, the reaction rate and conversion were found to be easily controlled by changing the permeate flux, which in turn could be controlled by changing the pressure. Therefore, we could control the reaction rate by changing the pressure.

Sucrose inversion is an important transformation process in the food industry, and several methods have been investigated for this purpose. A comparison between the volumetric productivities of sucrose inversion obtained by using different reactor systems is summarized in Table I. Greco et al. ${ }^{25)}$ analyzed the kinetics of soluble invertase in an unstirred UF cell. The volumetric productivity was calculated to be $3.6 \times 10^{-4} \mathrm{~mol} \cdot \mathrm{m}^{-3} \cdot \mathrm{sec}^{-1}$, which was very low because of the low concentration of the enzyme. Using a CSTR with a UF membrane, a low value of $0.09 \mathrm{~mol} \cdot \mathrm{m}^{-3} \cdot \mathrm{sec}^{-1}$ was obtained. ${ }^{16)}$ Cogelled invertase was also used in an unstirred UF cell, and productivity was in the order of $10^{-4} \mathrm{~mol} \cdot \mathrm{m}^{-3} \cdot \mathrm{sec}^{-1} \cdot{ }^{25)}$ The conversion obtained in these stirred and unstirred tank reactors with UF systems was not high, because both the substrate and product permeated through the membranes. Using invertase bound and covalently coupled to concanavalin A-Sephalose, ${ }^{26)}$ the volumetric productivity was estimated to be $0.71 \mathrm{~mol} \cdot \mathrm{m}^{-3}$. $\mathrm{sec}^{-1}$. Kawashima et al. ${ }^{27)}$ also investigated sucrose inversion with an immobilized enzyme by a radiopolymerization method. A $30 \%$ sucrose solution was almost completely decomposed by the membraneous immobilized invertase column at a space velocity of $3 \mathrm{hr}^{-1}$. The volumetric productivity obtained with the column was estimated to be $0.73 \mathrm{~mol} \cdot \mathrm{m}^{-3}$. $\mathrm{sec}^{-1}$. As mentioned by Iqbal et al., immobilized cell systems with invertase activity were less efficient because of low enzyme concentrations. $^{26)}$ The volumetric productivity of $0.5 \sim 1.4 \mathrm{~mol} \cdot \mathrm{m}^{-3} \cdot \mathrm{sec}^{-1}$ obtained in this study was somewhat higher than has been previously observed. We adopted the volume of a membrane module as the reactor volume in the present system. Hence, the higher volumetric productivity observed with this system might
TABle I. Comparison Bet WeEn the Productivity of Different Reactor Systems FOR SUCROSE INVERSION

\begin{tabular}{llcc}
\hline $\begin{array}{l}\text { Reactor } \\
\text { type }\end{array}$ & $\begin{array}{c}\text { Reaction rate } \\
\left(\mathrm{mol} \cdot \mathrm{m}^{-3} \cdot \mathrm{sec}^{-1}\right)\end{array}$ & $\begin{array}{c}\text { Conver- } \\
\text { sion } \\
(\%)\end{array}$ & \\
\hline $\begin{array}{l}\text { Unstirred } \\
\text { tank reactor } \\
\text { with UF }\end{array}$ & $3.6 \times 10^{-4}$ & 48 & $\begin{array}{c}\text { Greco } \text { et al. } \\
(1979)\end{array}$ \\
\hline $\begin{array}{l}\text { CSTR/UF } \\
\text { Immobilized } \\
\text { enzyme }\end{array}$ & 0.053 & 43 & $\begin{array}{c}\text { Bowski } \text { et al. } \\
(1972)\end{array}$ \\
\hline $\begin{array}{l}\text { Immobilized } \\
\text { enzyme }\end{array}$ & 0.73 & 80 & $\begin{array}{c}\text { Iqbal et al. } \\
(1985)\end{array}$ \\
\hline $\begin{array}{l}\text { Forced } \\
\text { flow }\end{array}$ & $0.5 \sim 1.4$ & $>90$ & $\begin{array}{c}\text { Kawashima } \text { et al. } \\
\text { This study }\end{array}$ \\
\hline
\end{tabular}

have resulted from a higher concentration of enzyme within the membrane.

Further simulated results for the forced-flow system under different values of maximum reaction rate are shown as solid lines in Fig. 5. The plateau values of glucose flux were proportional to the values of the maximum reaction rate, which may reflect the quantity of immobilized enzyme. For higher productivity in the system, more immobilization of the enzyme is required. Recently, a relatively large quantity of enzyme has been immobilized within a porous ceramic membrane by the technique of covalent coupling of silaneglutaraldehyde, and much greater productivity was obtained. ${ }^{28)}$

Compared with commercial polymer membranes, ceramic membranes are more durable against high temperatures and chemical agents. When the enzyme activity has decreased, the enzyme can be removed from a ceramic membrane by sodium hypochlorite solution: Because they can be sterilized and reused, ceramic membranes are good carriers of immobilized enzymes or biocatalysts. The forced-flow system presented here was found to have a high potential for practical use. 


\section{CONCLUSION}

A forced-flow type of MBR for lowmolecular-weight substrates was developed. Forced-flow and diffusion-controlled systems were mathematically modeled, and the simulated results were in good agreement with the experimental results. The reaction rate in the forced-flow system was much higher than that in the diffusion-controlled system. The forced flow system has advantages for the hydrolysis of low-molecular-weight substrates, including high volumetric productivity and simple control of the reaction rate by pressure.

Acknowledgments. This work was supported by the Biomass Conversion Project of the Ministry of Agriculture, Forestry and Fisheries (BCP-87-V-2-5). We express sincere appreciation to Dr. M. E. Matthews of Nippon Proteins Co., Ltd., Japan, for his helpful review of the manuscript.

\section{NOMENCLATURE}

English alphabet

$C=$ sucrose concentration

$C_{1}=$ sucrose concentration in the feed solution

$D=$ diffusion coefficient of sucrose or glucose

$G \quad=$ glucose concentration

$J_{\mathrm{v}} \quad=$ permeate flux

$K_{\mathrm{m}}=$ Michaelis-Menten constant for the substrate

$\left[\mathrm{mol} \cdot \mathrm{m}^{-3}\right]$

$\left[\mathrm{mol} \cdot \mathrm{m}^{-3}\right]$

$\left[\mathrm{m}^{2} \cdot \mathrm{s}^{-1}\right]$

$\left[\mathrm{mol} \cdot \mathrm{m}^{-3}\right]$ $\left[\mathrm{m}^{3} \cdot \mathrm{m}^{-2} \cdot \mathrm{sec}^{-1}\right]$

$\left[\mathrm{mol} \cdot \mathrm{m}^{-3}\right]$

$L=$ thickness of the ceramic membrane [m]

$N_{\mathrm{g}}=$ glucose flux due to diffusion in a forced-flow system $\left[\mathrm{mol} \cdot \mathrm{m}^{-2} \cdot \mathrm{sec}^{-1}\right]$

$N_{\mathrm{g} 0}=$ glucose flux due to diffusion in a diffusioncontrolled system

$\left[\mathrm{mol} \cdot \mathrm{m}^{-2} \cdot \mathrm{sec}^{-1}\right]$

$r \quad=$ radial coordinate

$r_{0} \quad=$ inner radius of the membrane

$U_{\mathrm{g}}=$ glucose flux due to convective flow in a forced-flow system $\quad\left[\mathrm{mol} \cdot \mathrm{m}^{-2} \cdot \mathrm{sec}^{-1}\right]$

$U_{\mathrm{s}} \quad=$ sucrose flux due to convective flow in a forced-flow system $\quad\left[\mathrm{mol} \cdot \mathrm{m}^{-2} \cdot \mathrm{sec}^{-1}\right]$

$u=$ permeation velocity in a porous ceramic membrane

$\left[\mathrm{m} \cdot \mathrm{sec}^{-1}\right]$

$u_{1} \quad=$ permeation velocity at the outer wall of the ceramic membrane

$\left[\mathrm{m} \cdot \mathrm{sec}^{-1}\right]$

$V_{\mathrm{m}}=$ maximum reaction rate in a porous ceramic membrane

$\left[\mathrm{mol} \cdot \mathrm{m}^{-3} \cdot \mathrm{sec}^{-1}\right]$

Greek alphabet

$\alpha=$ dimensionless parameter defined by Eq. (8) [-] $\beta_{\mathrm{u}}=$ dimensionless parameter defined by Eq. (8) [-]

$\beta_{\mathrm{d}}=$ dimensionless parameter defined by Eq. (18) [-]

$\gamma=K_{\mathrm{m}} / C_{1}$ [-]

$\varepsilon=$ porosity $[-]$

$\xi=$ dimensionless radial coordinate $\quad[-]$

$\theta=$ normalized sucrose concentration $\quad[-]$

$\tau=$ normalized glucose concentration $\quad[-]$

\section{REFERENCES}

1) I. Chibata, "Food Process Engineering," Vol. 2, ed. by Linko and Larinkari, Applied Science Publishers, London, 1981, p. 1.

2) S. Sourirajan and T. Matsuura, "Reverse Osmosis and Ultrafiltration," ACS Symp. Series, 1985, p. 1.

3) M. Cheryan and M. A. Mehaia, "Membrane Separation in Biotechnology," ed. by W. C. McGregor, Dekker, New York, 1986, p. 255.

4) A. S. Michaels and S. L. Matson, Desalination, 53, 231 (1985).

5) A. S. Michaels and H. Strathmann, J. Membrane Sci., 15, 118 (1981).

6) V. C. Gekas, Enzyme Microb. Technol., 8, 450 (1986).

7) W. D. Deeslie and M. Cheryan, J. Food Sci., 46, 1035 (1981).

8) W. D. Deeslie and M. Cheryan, Biotechnol. Bioeng., 24, 69 (1982).

9) H. E. Klei, D. W. Sundstrom, R. W. Coughlin and K. Ziolkowski, Biotechnol. Bioeng. Symp.; 11, 593 (1981).

10) I. Ohlson, G. Tragardh and B. H. Hagerdal, Biotechnol. Bioeng., 24, 647 (1984).

11) F. Alfani, M. Cantarella and V. Scardi, J. Membrane Sci., 16, 407 (1982).

12) S. C. Bhumiratana, C. G. Hill and C. H. Amundson, J. Food Sci., 42, 1016 (1977).

13) R. W. Silman, L. T. Black, J. E. McGhee and E. B. Bagley, Biotechnol. Bioeng., 22, 533 (1980).

14) J. M. Engasser, J. Caumon and A. Marc, Chem. Eng. Sci., 35, 99 (1980).

15) J. E. Prenosil and J. E. Hediger, Desalination, 53, 265 (1985).

16) L. Bowski, P. M. Shah, D. Y. Ryu and W. R. Vieth, Biotechnol. Bioeng. Symp., 3, 329 (1972).

17) M. L. Leiva and V. Gekas, Process Biochemistry, 21, 27 (1986).

18) Nitto products catalogue, Membrane master (1987).

19) Y. Sahashi, T. Okada and T. Hibino, Annual Meeting of Nippon Nōugeikagaku Kai, 1987, p. 380.

20) S. Adachi, K. Hashimoto, R. Matsuno, K. Nakanishi and T. Kamikubo, Biotechnol. Bioeng., 22, $779(1980)$.

21) D. Combes and P. Monsan, Carbohydr. Res., 117, $215(1987)$.

22) T. E. Barman, "Enzyme Handbook," Vol. II. Springer-Verlag, Berlin, 1969, p. 586.

23) H. Matsuyama, "Basic Technology of Micro- 
computer," Kagakukougaku-Kyoukai, Kansai 26) J. Iqbal and M. Saleemuddin, Enzyme Microb. Branch, 1986, p. 45. Technol., 7, 175 (1985).

24) "Kagaku Kougaku Binran," 4th Ed., Maruzen, 27) K. Kawashima, T. Suzuki and K. Umeda, Nippon Tokyo, 1978, p. 70. Shokuhin Kogyo Gakkaishi, 23, 588 (1976).

25) G. Greco, F. Alfani, G. Iorio, M. Cantarella, A. 28) M. Nakajima, N. Jinbo, K. Nishizawa, H. Nabetani, Formisano, L. Gianfreda, R. Palescandolo and V. A. Watanabe and S. Nakao, Int. Congress on Scardi, Biotechnol. Bioeng., 21, 1421 (1979). Membranes, 1987 , p. 453. 